\title{
LIVER HISTOPATHOLOGY OF THE FISH BRACHYDANIO RERIO HAMILTON-BUCHMAN AFTER ACUTE EXPOSURE TO SUBLETHAL LEVELS OF THE ORGANOPHOSPHATE DIMETHOATE 500
}

\author{
Edson de Lara Rodrigues ${ }^{1}$ \\ Edith Fanta ${ }^{2}$
}

\begin{abstract}
Among the new substances that were synthesised by the chemical industry during the last decades, with the aim to improve human prosperity, some cause negative effects on non target organisms like fish. Among the pesticides, the organophosphates (OP) are widely used in cattle management, agriculture and aquaculture activities. Brachydanio rerio Hamilton-Buchman, 1822 is used world-wide in fishtests for the establishment of the lethal levels of pesticides. Nevertheless, these fish show morphological changes in their hepatocytes when exposed experimentally for 24 hours to the sublethal dose of $0.025 \mu \mathrm{l} / \mathrm{l}$ of the OP Dimethoate 500, in acute tests. Eight hours after exposure, a high density of cells with cytoplasmic granulation is seen as well as focal necrosis. The main changes that occurred in the first 24 hours of exposure were the loss of the typical polygonal cell shape and of detectable cell limits, lateral migration of nuclei, nuclear size and shape, condensation of chromatin and pycnosis, increased cytoplasmic granulation followed by vacuolisation. After 48 hours in clean water, 72 hours from contamination, besides significant morphological changes and necrosis, focal regeneration of the hepatocytes, canaliculi, ducts and sinusoids were seen. Even having been exposed to the half of the dose considered as safe according to the general pesticide allowance rules, significant changes of the liver tissue were observed.

KEY WORDS. Dimethoate, histopathology, fish, liver, organophosphates, sublethal contamination
\end{abstract}

Human population growth led to the need for increase in food production. Therefore, chemical pest control was developed. If on one hand humanity achieved prosperity, on the other hand this has been accompanied by significant health and environmental risks, due to the nature of the chemicals themselves. Sometimes they act on non target organisms like mammals or fish or even man. Among substances that are introduced in the environment, potentially polluting water, soil and food, the organophosphates (OP) are widely used in agriculture and farm animals management, as well as in aquaculture.

The use of organophosphates started after the detection of their inhibitory effects on acethylcholinesterase (KoELLE \& GILMAN 1949). The toxicological

1) Instituto Adventista de Ensino, Faculdade Adventista de Ciências. Caixa Postal 12630, 04744-970 São Paulo, São Paulo, Brazil.

2) Correspondence to: Universidade Federal do Paraná, Departamento de Biologia Celular. Caixa Postal 19031, 81531-970 Curitiba, Paraná, Brazil. 
effects of OP on vertebrates are mainly manifested by phosphorilation of AchE (COPPAGE 1972), decrease of the levels of norepinephrine (BRZEZINSKI \& WYSOCKA-PARUSZEWSKA 1988), skeleton deformation and reduction of the gonad somatic index (KUMAR \& ANSARI 1984), defects on embryo development and egg hatching (ANSARI \& KUMAR 1988) and pathological changes in the ovary (ANSARI et al. 1986). PICKERING et al. (1962) and ALABASTER (1969) established the toxicity of organophosphates for different fish species, recognising that it varies with age, weight and sex of the animals as well as the composition of the active principle of the products. Fish exposed to pesticides in the laboratory, as well as those obtained in the nature after detection of aquatic pollution, show pathologies in the liver (BENDER 1969; ANEES 1978; GILl et al. 1988; KUMAR \& ANSARI 1986).

Due to the need on information about the potential effects of pesticides that may pollute the water, and the definition of the toxicological class of products and the allowed amounts to be used, fish tests were established as a necessary routine. Acute toxicity tests are useful to determine the symptoms consequent to administration of compounds and to determine their order of lethality (LOOMIS \& HAYES 1996).

The freshwater fish Brachydanio rerio Hamilton-Buchman, 1822 is used world-wide as test fish as it is easy to maintain in tanks, it reproduces in the laboratory and is sensitive to the effects of toxic substances (LAALE 1977). Therefore this same fish was chosen for this study about the possible histopathological effects of the OP Dimethoate in a sub-lethal concentration. Sub-lethal concentrations are usually considered safe because they do not cause death. But, as the liver has many vital functions, besides bile secretion, like metabolism of proteins, lipids and carbohydrates, storage of nutrients and detoxification, changes in its morphology and necrosis will certainly cause secondary consequences to the organism, impairing its fitness for life, even if it survives after having been contaminated.

\section{MATERIAL AND METHODS}

Fish tests were done with 250 adult individuals from the same brood of a freshwater fish, Brachydanio rerio Hamilton-Buchnan, 1822 (Cyprinidae), with 2.5 to $3.5 \mathrm{~cm}$ total length and $0.17 \mathrm{~g}$ mean weight. The fish were maintained for acclimation for two weeks in $250 \mathrm{~L}$ aquariums, in filtered and dechlorinated tap water, at the temperature of $25^{\circ} \mathrm{C}\left( \pm 1^{\circ} \mathrm{C}\right), \mathrm{pH} 7( \pm 0.2)$ and a photoperiod of 10 hours light/14 hours darkness. The animals were fed twice a day, at the beginning and at the end of the light period with commercial food.

After acclimation, 100 fish were used for the determination of the $\mathrm{LC}_{50}$ (OP concentration that is lethal for $50 \%$ of the population) and 150 individuals for tests with a sublethal dose, all of them maintained at the same environmental conditions as during acclimation.

Dimethoate $500^{\circledR}$ (Nortox) was chosen because it is widely used in the state of Paraná (Brazil) and is soluble in water.

The $\mathrm{LC}_{50}$ was determined in two steps: (i) establishment of the range between the highest concentration resulting in $0 \%$ mortality and the lowest concen- 
tration with $100 \%$ mortality being tested the concentrations of $0.5,0.1,0.01,0.001$, $0.0001,0.00001 \mathrm{~mL} / \mathrm{L}$ of Dimethoate 500 and one uncontaminated control; (ii) increasing dilution between both extremes of phase (i) namely $0.01,0.10,0.12$ and $0.14 \mu \mathrm{L} / \mathrm{L}$ for the establishment of the $\mathrm{LC}_{50}$ in an acute 96 hours test. Every 24 hours the number of death individuals was registered and the abiotic parameters measures. The temperature was maintained at $24.8^{\circ} \mathrm{C}\left( \pm 0.2^{\circ} \mathrm{C}\right)$, the conductivity at $159.62 \mu \mathrm{S} / \mathrm{cm}( \pm 6.5 \mu \mathrm{S} / \mathrm{cm})$, the $\mathrm{pH}$ at $7.15( \pm 0.05)$ and the dissolved oxygen at $7.5 \mathrm{mg} / \mathrm{L}( \pm 0.2 \mathrm{mg} / \mathrm{L})$.

Thereafter, the sublethal dose of $0.025 \mu \mathrm{L} / \mathrm{L}$ of the commercial product Dimethoate $500^{\mathbb{B}}$ (Nortox), corresponding to $50 \%$ of the LC 50 , and containing $0.0125 \mathrm{mg}$ of the active principle, was used in the acute experiments.

The fish tests were conducted for 72 hours in $40 \mathrm{~L}$ aquariums maintained in the same abiotic conditions as for the establishment of the $\mathrm{LC}_{50}$ : 50 individuals were contaminated for 24 hours and than transferred to an aquarium with clean water; 50 individuals were kept for the same period in clean water for control. Samples of liver were collected from experimental and control animals 2,4,8,24 and 72 hours after the beginning of contamination (To).

The liver tissue was prepared for optical microscopy, being fixed with Bouin's fluid for 6 hours. After fixation it was washed extensively in $70 \%$ alcohol and routine dehydrated. It was embedded in Paraplast plus ${ }^{\circledR}$ (Sigma) and the $3 \mu \mathrm{m}$ sections of experimental and control livers were stained simultaneously with HE (CULLing et al. 1985) and photographed at an Olympus photomicroscope.

\section{RESULTS}

\section{Determination of the sublethal concentration of Dimenthoate $\mathbf{5 0 0}$ for Brachydanio rerio}

At the concentration of $0.01 \mu \mathrm{L} / \mathrm{L}$ of Dimethoate 500 , survival was $100 \%$ in 96 hours of test; at $0.10 \mu \mathrm{L} / \mathrm{L} 13$ fish of 20 died, 3 after 72 hours and 10 after 96 hours; at $0.12 \mu \mathrm{L} / \mathrm{L}$ all 20 individuals died in 96 hours, 8 after 24 hours, other 8 after 48 hours and the last 4 after 72 hours; at $0.14 \mu \mathrm{l} / \mathrm{L} 19$ individuals died after 24 hours and all 20 were dead in 48 hours. Survival was $100 \%$ for the control fish during the same period.

These data were analysed by the "Trimmed Spearman Karber" method being the $\mathrm{LC}_{50}$ calculated as $0.048849 \mu \mathrm{L} / \mathrm{L}$, with the $95 \%$ upper confidence limit 0.06 and the $95 \%$ lower confidence limit 0.04 .

Therefore, the temporal sequence of effects on the liver of B.rerio was analysed after exposure to a sublethal dose of $0.025 \mu \mathrm{L} / \mathrm{L}$ of the commercial product Dimethoate $500^{\circ}$ (Nortox), corresponding to $50 \%$ of the $\mathrm{LC}_{50}$, and containing $0.0125 \mathrm{mg}$ of the active principle.

\section{Liver morphology of the control Brachydanio rerio}

The volume of the liver is proportionally big if compared to the body volume, showing slightly yellow colour and soft consistency. It is located in the anterior part 
of the abdominal cavity, covering partially the dorsal and the ventral part of the stomach. It is divided into three lobes, two bigger ones ventral to the stomach and a third smaller one dorsal to the stomach. The hepatic artery and portal vein enter the liver.

Cord-like structures are formed by the roundish polygonal hepatocytes that are limited at one side by the liver capillaries or sinusoids lined by simple squamous epithelium. Central to each cord are thin bile canaliculi adjacent to the hepatocytes. The boundaries between hepatocytes are easily discernible. The nucleus is proportionally big, spherical, centrally placed, with concentrated chromatin and prominent nucleoli (Fig. 1). The cytoplasm is foamy due to the presence of lipid and glycogen deposits that are removed by routine histological techniques and showing some eosinophilic granulation. Some lymphocytes with spherical small nucleus and moderately peripheral condensed chromatin can be identified. Granulocytes and probably macrophages occur in small number.

\section{Histological changes in the liver of $B$. rerio under the effect of sublethal levels of Dimethoate $\mathbf{5 0 0}$}

After 2 hours of exposition to the OP the liver presented some pathological changes when compared to the control. Cells were swollen, the cell outline becoming indistinguishable. Some nuclei became lateral in the cell, showing variable shape and size, some with condensed chromatin that seemed to adhere the nuclear membrane. A higher cytoplasm vacuolisation was noticed in some hepatocytes in different areas of the liver, but in others the cytoplasm showed a higher density of granules (Fig. 2).

The OP provoked cloudy swelling of the hepatocytes after a four hours exposition. As a consequence synusoids and canalicules became slender. Coarse and fine grains inside the hepatocytes were more reactive to eosin than in the control. The boundary of many cells was no more visible. Some nuclei still had a regular shape and central position in the cell but others were small and pycnotic. Focal necrosis and focal cellular vacuolisation were observed side by side with normal cells (Fig. 3).

When exposed for 8 hours to the OP, more regions of the liver showed focus of necrosis. The nuclei in different hepatocytes showed diverse diameters and degrees of density: some presented condensed chromatin in the central region and others were extremely pycnotic, progressing into karyolysis and leading to focal necrosis and cytolysis. Big vacuoles are present in most of the cells (Fig. 4).

Twenty four hours of exposure to the OP caused extended regions in the liver to be totally necrotic and haemorrhagic. Hepatocytes varied in their morphology, some showing lateral nuclei, some in degeneration, others highly pycnotic. Cytoplasm was granular or showed vacuolar degeneration (Fig. 5). Probably due to cytolysis, infiltration of macrophages or phagocytes increased in these regions.

After 24 hours the fish were placed in fresh water. So, 72 hours from the beginning of the experiment, or after 48 hours in fresh water, there were still significant morphological changes in the liver cells. Focal necrosis with cytolysis was still observed and cysts are formed in the centre of these areas. Many cells 
showed lateral nuclei and irregular vacuoles (Fig. 6). But, on the other hand, in certain regions hepatocytes, bile ducts and sinusoids seem to be in different stages of regeneration.
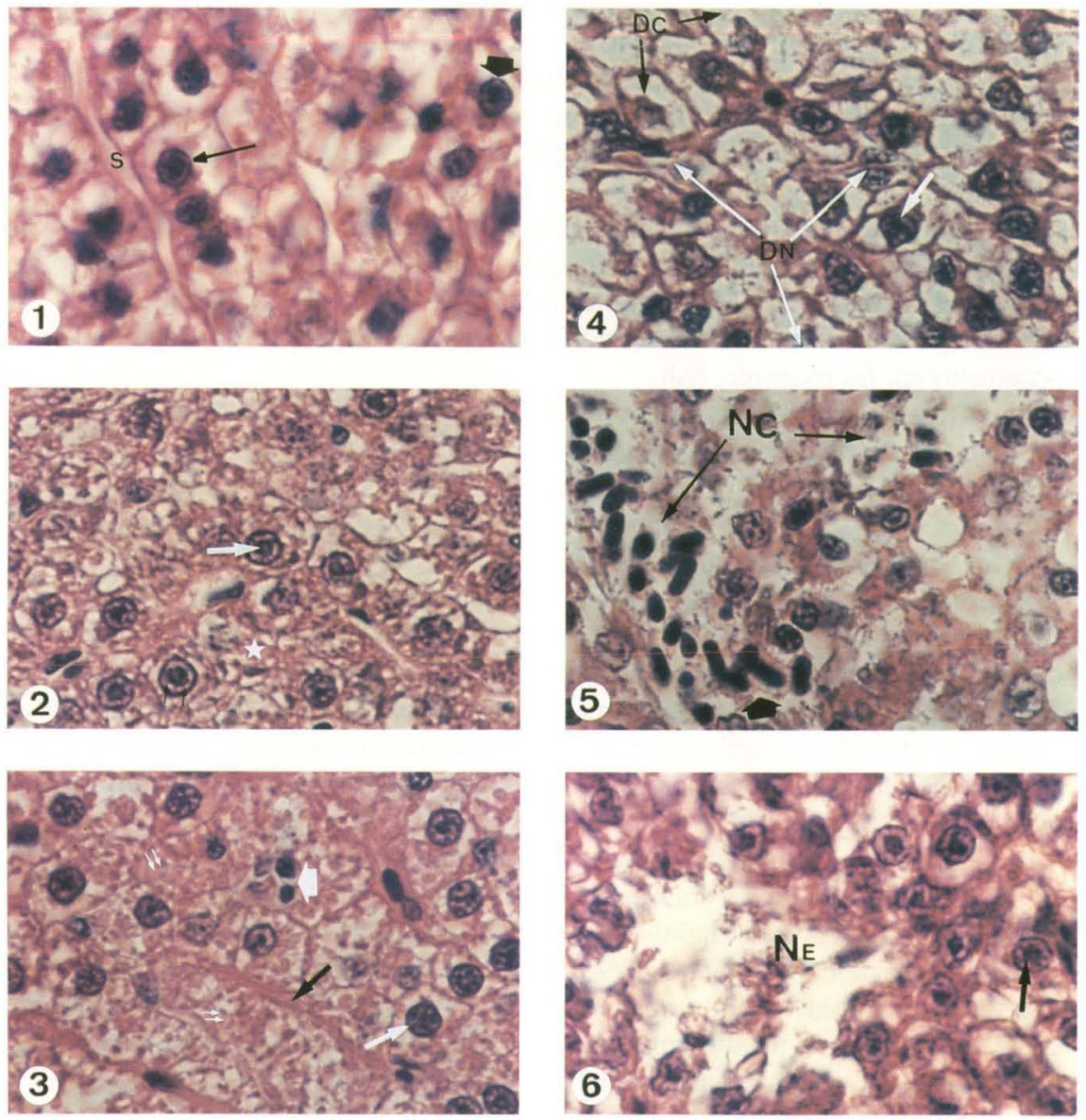

Figs 1-6. Liver cells of Brachydanio rerio, H.E.. (1) Section of a control liver - polygonal hepatocytes cords (small arrow); central nuclei and nucleoli (short arrow); cytoplasmic vacuoles; sinusoids (S). (2) 2 hours after contamination with the OP: swollen hepatic cells; lateral nuclei (arrow), some with irregular shape and size and karyolyse (star); vacuoles and granulation in the hepatocytes. (3) 4 hours after contamination with the OP: heavy granulation of the hepatocytes (double small arrows); small and pycnotic nuclei (wide arrow) besides some with dense chromatin (white long arrow); small synusoids (long black arrow). (4) 8 hours after contamination with the OP: nuclei with different sizes and shapes (white arrow); vacuolar degeneration (DC); focal necrosis (DN). (5) 24 hours after treatment with the OP: haemorrhage (short arrow); hepatocyte and sinusoid necrosis and cytolysis (N). (6) 48 hours in clean water, 72 hours from the beginning of the treatment with the OP: intense focal necrosis with cytolysis and cyst (NE); some hepatocytes are regenerated (arrow). 


\section{DISCUSSION}

Pesticides in general allowed an expansion of agricultural activities in order to supply the increasing world population with food, mainly after World War II. However, a superficial knowledge of the toxicity of these products lead to an exaggerated use, resulting in uncontrolled environmental contamination. The pollutants affect food chains in different environments and also humans, not only due to the ingestion of contaminated food, but also by inadequate handling of the toxic products.

Dimethoate is a carboxyamide organophosphorous pesticide, largely used, even in the state of Paraná (Brazil), for agricultural plague control. It is a foliar spray with long residual life (MATSUMURA 1985). Being soluble in water, it may be carried by surface water and rain into freshwater bodies, contaminating non target organisms as, for example, fish.

Based on the determination of a CL50 of 58 ppt of the Dimethoate Rogor 40 for Salmo gairdnerii it was classified by ALABASTER (1969) as a product of medium toxicity when compared to other pesticides. But for Therapon jarbua the Rogor CL50 was only $0.70 \mathrm{ppt}$ in a static fish test (LINGARAJA \& VÉNUGOPALAN 1978) and for Saccobranchus fossilis the CL50 was 4.57 ppt (VERMA et al. 1982). Therefore, as for Brachydanio rerio the Dimethoate 500 CL50 was 0.048 ppt, one can conclude that this species shows a high sensibility to the product, and that different species have different sensibility levels for the same OP pesticide.

In general, the more commonly used $\mathrm{OP}$ cause poisoning symptoms that are similar in intensity and seriousness if taken in one single dose or in successive small doses, when a critical level is accumulated, leading to severe and chronic consequences (SILVA et al. 1993).

Even considering the distance between man and fish, some of the symptoms are common to both and a consequence of the direct action of the toxic substance on the liver cells, being mainly biochemical effects (LOOMIS \& HAYES 1996). LARINI (1979) and SILVA et al. (1993) believe that some of the OP compounds are less toxic to mammals than to fish. But even men show, besides other symptoms, some that are certainly the consequence of hepatic pathologies like diminished hunger, nausea, vomit and abdominal pain (LARINI 1979).

Fish tests are valuable for a controlled experimentation with toxic substances and the evaluation of their effects on different species in a temporal sequence. Therefore all other conditions have to be maintained constant so that the only variable is the concentration of the substance to be tested (FANTA 1991, 1994; BRASIL 1988). The species Brachydanio rerio was described as being very useful for fish tests (LAALE 1977) and has been used world-wide for the determination of the toxicity levels of pesticides.

The effect of OP pesticides in general on fish liver was described for different species by PICKERING et al. 1962; FANTA 1997; SILVA et al. 1993). Its absorption in the present experiment was through the gills. The diffusion of OP depends on lipid solubility and the removal by the blood depend on the lipid content of the blood or special carriers (RANDALL et al. 1996). This was the reason for some changes in the liver cell morphology being observed first close to blood vessels. 
There are some basic pathologies that pollutants in general may cause to fish liver, like: swelling, disorganisation of hepatic cords, increased level of mitosis in liver parenchyma cells, changes in nuclear size and shape, nuclear migration of nuclei and focal necrosis (HIBYA 1982). These aspects were observed for Salmo clarki exposed chronically to Endrin (ELLER 1971); Brachydanio rerio exposed to DDT showed increase in lipid droplets and diminishing of the hepatocyte size (WEISS 1974); methyl mercury in Ictalurus punctatus liver produced focal necrosis and high vacuolisation (KENDALL 1977); copper accumulation in the liver of Morone americana resulted in hyperplasia of the bile ducts (BUNTON et al. 1987); the liver of Brachydanio rerio exposed to 4-nitrofenol showed swollen hepatocytes and an invasion of macrophages in the intracellular space as well as binucleated cells (BRAUNBECK et al. 1989); Tilapia rendalli exposed to the OP Folidol 600 (Methyl parathion) showed cloudy swelling of hepatocytes, nuclear decentralisation, vacuolisation, increase in basophilia and focal necrosis (E. Fanta, personal communication); GILL et al. (1990) verified an increase in lipids in the liver of Puntius conchonius exposed to the OP phosphamidon.

SILVA et al. (1993) admit the possibility that the methyl parathion that combines with the serine at the active site of cholinesterase, may experience a similar property with other proteins, therefore affecting the normal activity of organs such as the liver. According to MATSUMURA (1985), Dimethoate is a carboxyamide and therefore cannot be hydrolysed by carboxylesterases. By amidase it is transformed in dimethoate acid and by hydrolysis in phosphoric acid derivatives. The liver microsomal fraction contains carboxyamidase but it is not mediated by oxidative enzymes. Its identity and properties have not been studied yet KUMAR \& ANSARI (1986) and ANSARI \& KUMAR (1988) evaluated the toxicological and pathological effects of the OP Malathion in the liver of Brachydanio rerio, and noticed a decrease in the protein levels, inhibition of DNA and RNA and increase of free aminoacids. This leads to some of the morphological changes here observed at tissue level. ANNES (1978) described the pathological changes for Channa punctatus when exposed to Dimethoate in a sublethal doses of 8 ppt as cytoplasm vacuolisation, cytoplasm granules but only after 24 hours, what in $B$. rerio was seen after 4 hours ofd exposure. GiLl et al. (1988) using Dimethoate in Puntius conchonius show the same results as in the present study.

So, analysing the changes that were observed, even after a sublethal short exposure to Dimethoate 400, Brachydanio rerio showed all the above mentioned tissue pathologies in its liver. It seems that there is a temporal sequence of the events that start with decentralisation of some hepatocyte nuclei and increase in granulation of their cytoplasm, followed by vacuolisation, cloudy swelling, nuclear intense pigmentation, necrosis, invasion of macrophages and canaliculi swelling. After the cessation of the impact, a focal recovering was seen.

When the product of metabolic transformation is highly toxic, the inhibition of the metabolising enzymes and the necrosis of the metabolising cells protect the animal from toxicity that results from metabolism (LOOMIS \& HAYES 1996). Therefore, the liver lesions produced by the OPs in general and as seen here, by Dimethoate, are useful to the fish. 
It was noticed that the action of this pesticide in sublethal levels did not affect the liver as a whole, but focally. Therefore, a short exposure and a sublethal level of Dimethoate allows a recovery. But as happens in other species and under the action of varied pollutants, one can assume that if the action is repeated or stronger, these effects may cause some chronic alterations and tumours in the case of OP contamination.

Liver changes affect directly the metabolism of fish therefore diminishing its life fitness. One can conclude that, with weakened health they may be easily predated, will have lower reproductive capacity and might loose in competition for space or food. Therefore, from an ecological point of view, there might be a change in the population and in the food chains.

The important aspect of this research is, besides the description of the histopathological effects of Dimethoate on the liver, the detection that some of them are significant and appear very shortly after exposure. One wants to point out that the observed effects are serious if considered that the concentration of the product used in the tests is considered safe according to a perspective of environmental safety. Ecological consequences may be significant if the action of the pesticide persists.

Therefore, not only one can recommend that the allowed levels for pesticides should be lower to make them really more secure, that the exposure shall be the shortest as possible and that different species should be tested as their sensitivity may vary.

ACKNOWLEDGEMENTS. The research was conducted with a grant from FUNPAR/UFPR, a CNPq Master Stipend for E.L. Rodrigues, and a CNPq Scientist Stipend for E.Fanta. The authors wish to thank the Biologists A.C.Vianna and S.Romão for the histological photography.

\section{REFERENCES}

ALABASTER, J.S. 1969. Survival of fish in 164 herbicides, insecticides, fungicides, wetting agents and miscellaneous substances. International Pest. Control.: 29-35.

ANNES, M.A. 1978. Hepatic pathology in a freshwater teleost Channa punctatus (Bloch) exposed to sublethal and chronic levels of three organophosphorus insecticides. Bull. Environ. Contam. Toxicol. 19: 525-527.

ANSARI, B.A. \& K. KUMAR. 1988. Diazinon toxicity: effect on protein and nucleic acid metabolism in the liver of zebrafish, Brachydanio rerio (Cyprinidae). Sci. Total Environ. 76 (1): 63-68.

Ansari, B.A.; R. SRIVASTAVA \& K. Kumar. 1986. Malathion toxicity: Pathological changes in the ovary of Zebrafish Brachydanio rerio (Cyprinidae). Bol. Fisiol. Anim. 10: 95-101.

BENDER, M.E. 1969. Uptake and retention of malathion by the carp. Fish-cult. 31: 155-159.

BRASIL, MinistÉRIO DA AGRICULTURA. 1988. Pesticidas: métodos de análise e informações técnicas. Curitiba, 1, p.91-93. 
Braunbeck, T.; V. STORCH \& R. NAgel. 1989. Sex-specific reaction of liver ultrastructure in Zebrafish, Brachydanio rerio after prolonged sublethal exposure to 4-nitrophenol. Aquat. Toxicol. 14 (3): 185-202.

BrzEZINSKI, J. \& B. WysockA-PARUSZEWSKA. 1988. Neurochemical alterations in rat brain as a test for studying the neurotoxicity of Organophosphorus Insecticides. Arch. Toxicol. 4: 479-481.

Bunton, T.E.; S.M. BAKsi; S.M. George \& J.M. Frazier. 1987. Abnormal hepatic copper storage in a Teleost fish (Morone americana). Vet. Pathol. 24 (6): 515-525.

Coppage, D.L. 1972. Organophosphate pesticides: specific level of brain AchE inhibition related to death in sheepshead minnows. Trans. Amer. Fish. Soc. 101: $534-540$.

Culling, C.F.A.; R.T. Allison \& W.T. BARR. 1985. Cellular pathology technique. London, Butterworth \& Co., 642p.

ELLER, L.L. 1971. Histopathological lesions in cutthroat trout Salmo clarki exposed chronically to the insecticide Endrin. Amer. Jour. Pathol. 64: 321-330.

FANTA, E. 1991. Ação de Poluentes sobre tecidos, p.32-37. In: H.S.L. SANTOS. (Ed.) Histologia de Peixes. Jaboticabal, FCAV-UNESP, 80p.

1994. Estudos de comportamento de peixes dentro de um contexto multidisciplinar e sua aplicação prática. Anais do Encontro de Etologia, Cananéia, 12: 14-30.

1997 Organofosforados: bons para a agricultura, ruins para os peixes. Germinis $1(1): 3-4$

GILL, T.S.; J. PANDE \& H. TEWARI. 1990. Sublethal effects of an organophosphorus insecticide on certain metabolite levels in a freshwater fish, Puntius conchonius (Hamilton). Pestic. Biochem. Physiol. 36 (3): 290-299.

Gill, T.S.; J.C. PANT \& J. PANT. 1988. Gill, liver and kidney lesions associated with experimental exposures to Carbaryl and Dimethoate in the fish Puntius conchonius (Ham.). Bull. Environ. Contam. Toxicol. 41 (1): 71-78.

HiBYA, T. 1982. An Atlas of Fish Histology: Normal and Pathological Features., p.82-90. Tokyo, Kodansha \& Gustav Fischer Verlag, 147p.

KENDALL, M.W. 1977. Acute effects of methyl mercury toxicity in channel catfish Ictalurus punctatus liver. Bull. Environ. Contam. Toxicol. 18: 143-147.

Koelle, G.B. \& A. Gilman. 1949. Anticholinesterase. Jour. Pharmacol. Exp. Ther. 95: 166-216.

KUMAR, K. \& B.A. ANSARI. 1984. Malathion toxicity: skeletal deformities in zebrafish Brachydanio rerio (Cyprinidae). Pest. Sci. 15: 107-111.

1986. Malathion toxicity: effect on the liver of the fish Brachydanio rerio (Cyprinidae). Ecotoxicol. Environ. Safety. 12: 199-205.

LAALE, H.W. 1977. The biology and use of zebrafish, Brachydanio rerio in fisheries research. Jour. Fish. Biol. 10: 121-173.

LARINI, L. 1979. Toxicologia dos Inseticidas. São Paulo, Sarvier, 172p.

Lingaraja, T.\& V.K. Venugopalan. 1978. Pesticides induced physiological and behavioural changes in an estuarine teleost Therapon jarbua (Forsk). Fish Technol. 15: 115-119.

LOOMIS, T.A. \& A.W. HAYES. 1996. Loomis essentials of toxicology. New York 
Acad. Press, 282p.

MAtsumura, F. 1985. Toxicology of insecticides. New York, Plenum Press, 598p. PICKERING, Q.H.; C. HENDERSON \& A.E. LENKE. 1962. The toxicity of organophosphorus insecticides to different species of warmwater fishes. Trans. Amer. Fish Soc. 91 (2): 175-184.

Randall, D.J.; C.J. Brauner; R.V. Thurston \& J.F. Neuman. 1996. Water chemistry at the gill surfaces of fish and the uptake of xenobiotics. In: E.W. TAYLOR (Ed.) Toxicology of aquatic pollution. Cambridge Univers. Press. Soc. Exptl. Biol. Seminar Ser. 57: 1-16.

Silva, H.C.; H.S.G. Medina; E. FanTA \& M. Bacila. 1993. Sub-lethal effects of the organophosphate Folidol 600 (Methyl Parathion) on Callichthys callichthys (Pisces: Teleostei). Comp. Biochem. Physiol. 105 (2): 197-201.

VERMA, S.R.; S.K. BANSAL \& A.K. GUPTA. 1982. Bioassay trials with twenty three pesticides to a freshwater teleost Saccobranchus fossilis. Water Res. 16: 525529.

WEISS, P. 1974. Ultrastructural changes induced by low concentrations of DDT in the livers of the zebrafish and guppy. Chem. Biol. Interact. 8: 25-30.

Recebido em 17.IV.1997; aceito em 10.VI.1998. 